\title{
Retrofitting of RC Frame Structure Using Performance Based Friction Damper
}

\author{
S. Kawalkar ${ }^{\# 1}$, S. Sanghai ${ }^{\# 2}$, P. Deshpande ${ }^{* 3}$ \\ ${ }^{\# 1,2}$ Civil engineering Department, G. H. Raisoni College of Engineering, Nagpur, Maharashtra, India. \\ ${ }^{1}$ shritej.kawalkar@gmail.com \\ ${ }^{2}$ sanket.sanghai@raisoni.net \\ * SPD Infra consultants Pvt. Ltd., Nagpur, Maharashtra, India. \\ ${ }^{3}$ spdinfra1@rediffmail.com
}

\begin{abstract}
India suffered from many earthquakes over last some decades. Analysis of those earthquake showed that large number of existing structures needs to be upgrade for seismic actions. Performance based earthquake engineering is recent focus of researchers. Present study focused on the seismic retrofitting of existing structures which are previously designed for gravity loads only, by using performance based design philosophy of friction damper. Storey displacement, inter-storey drift, axial force, maximum moment, maximum shear force, base shear variation and effectiveness of dampers are observed for each model and in each direction for seven records of time history earthquakes. Results showed that response of structure are well within the limits of codes provisions. Thus friction damper can be used effectively for seismic retrofitting of structures.
\end{abstract}

Keyword - Retrofitting, Pushover analysis, Friction damper, Time history analysis, Inter-storey drift.

\section{INTRODUCTION}

Earthquake is natural disaster phenomenon in which the motion of the tectonics plate under the earth crust causes the ample amount of energy to be liberated in the form of vibrations. Earthquakes are highly unpredictable and occur suddenly without any prior warning. Approximately 50,000 earthquakes occur in a year over the globe. During the earthquake large amount of energy is transmitted into structure which causes the damage to structures. Amount of damage is depends on pattern by which the energy gets transferred in the structure. India has series of earthquake history, Koyana earthquake strikes the koyana dam with magnitude 6.5 at 10 december 1967, causes 200 peoples deaths and 1500 injuries. Nepal and Bihar earthquake with magnitude 6.6 leads to 1004 people deaths and 16,000 injuries and lots of structural damage. Utterakshi earthquake (1991) of a magnitude 6.6 with PGA as $0.31 \mathrm{~g}$, causes 768 deaths and 5066 injuries. Several structures were damage with RC frame and load bearing. Mainly brick infill was damage and slabs got cracked. 30september 1993 killari earthquake with intensity of VIII, more than 30\% population was suffered from impact of earthquake. Bhuj earthquake (2001) at Gujrat occurred on 26 january 2001 of magnitude 7.7, destroyed nearly 400000 structures. Divesting effect of earthquake leads to develop and modify the earthquake design codes, which demands higher ductility requirements for safety of the structures. Day by day modification made under code, leads to that the structures become vulnerable which was designed by previous code. Such structures need the retrofitting for updated structural requirement.

India has population nearly 130 corers which creates the pressure on government agencies for fulfilment of their basic needs such as shelter, food, health services, and educational services. All such services needs infrastructure such as house for shelter, hospitals for medical services and schools for quality educational services. Large investment is concurred for developing infrastructure facilities so it becomes very important to increase the life of such structures as much as possible. Retrofitting strategies provides economical and sure solution to extend the life of infrastructures. Various retrofitting strategies are developed till date by the various researchers all over the world. . Olariu et.al [8] discussed the effectiveness of base isolation for seismic retrofitting of existing historically important structures, and showed effectiveness in controlling both floor acceleration and inter-storey drift. Gandelli et.al [9] retrofitted hospital building. Sanghai et.al [13] studied the available literature on combine effect of soil structure interaction and friction dampers and put forth effectiveness of friction dampers changes as soil condition changed. Wang et.al [10] upgraded 35 storeys steel moment-resisting frame by using three different dissipation devices and found none of them performs best under seismic consideration.

In this paper attempt is made to seismic retrofit the reinforced concrete (RC) frames by use of performance based design of friction dampers. Specific objective of study are i) To study requirement of retrofit of structure by pushover analysis. ii) To study response of structure before and after retrofitting of RC frames. 


\section{METHODOLOGY}

\section{A. Modelling \& Performance Evaluation}

A typical frame of $\mathrm{G}+5$ storey has selected for the present study. Two different plans are selected for purpose of retrofitting (Fig 1). Slab thickness considered as $100 \mathrm{~mm}$ and load has been transferred on beams as per yield line theory influence area. Stiff joint diaphragm has assigned to each model. Wall load calculated as per IS 875 part I unit weight recommendation has been equally distributed over beams. Live load and roof live load considered to be acting on both models is $2.5 \mathrm{kN} / \mathrm{m} 2$ and $1.5 \mathrm{KN} / \mathrm{m} 2$ respectively, according to IS 875 part II. Structures are assumed to be situated in seismic zone V $(0.36)$, having a response reduction factor 3 and a structural importance factor as 1.5 as per IS- 18932016 code. M20 grade of concrete and Fe415 grade of re-bars material has considered for modeling material. Confining reinforcement of $8 \mathrm{~mm}$ diameter of FE-415 grade has been used. Plinth level considered $1.5 \mathrm{~m}$ from foundation level and typical storey height is considered as $3 \mathrm{~m}$ for both the structures. As per IS-1893-2016, as live load is less than $3 \mathrm{kN} / \mathrm{m}^{2}$ so mass source has defined for the $25 \%$ of live load. Modeling plan and details are given in tabe-1.

Retrofitting guidelines are provided by foreign codes ATC-40, FEMA-356 and ASCE 41-13. All of the above codes also provide software modeling guidelines for analysis purpose. Present study followed FEMA-356 modeling guidelines. Codes suggest nonlinear analysis for the structural evaluation. Proposed retrofitting methodology follows the following steps

TABLE I: Modelling Parameter

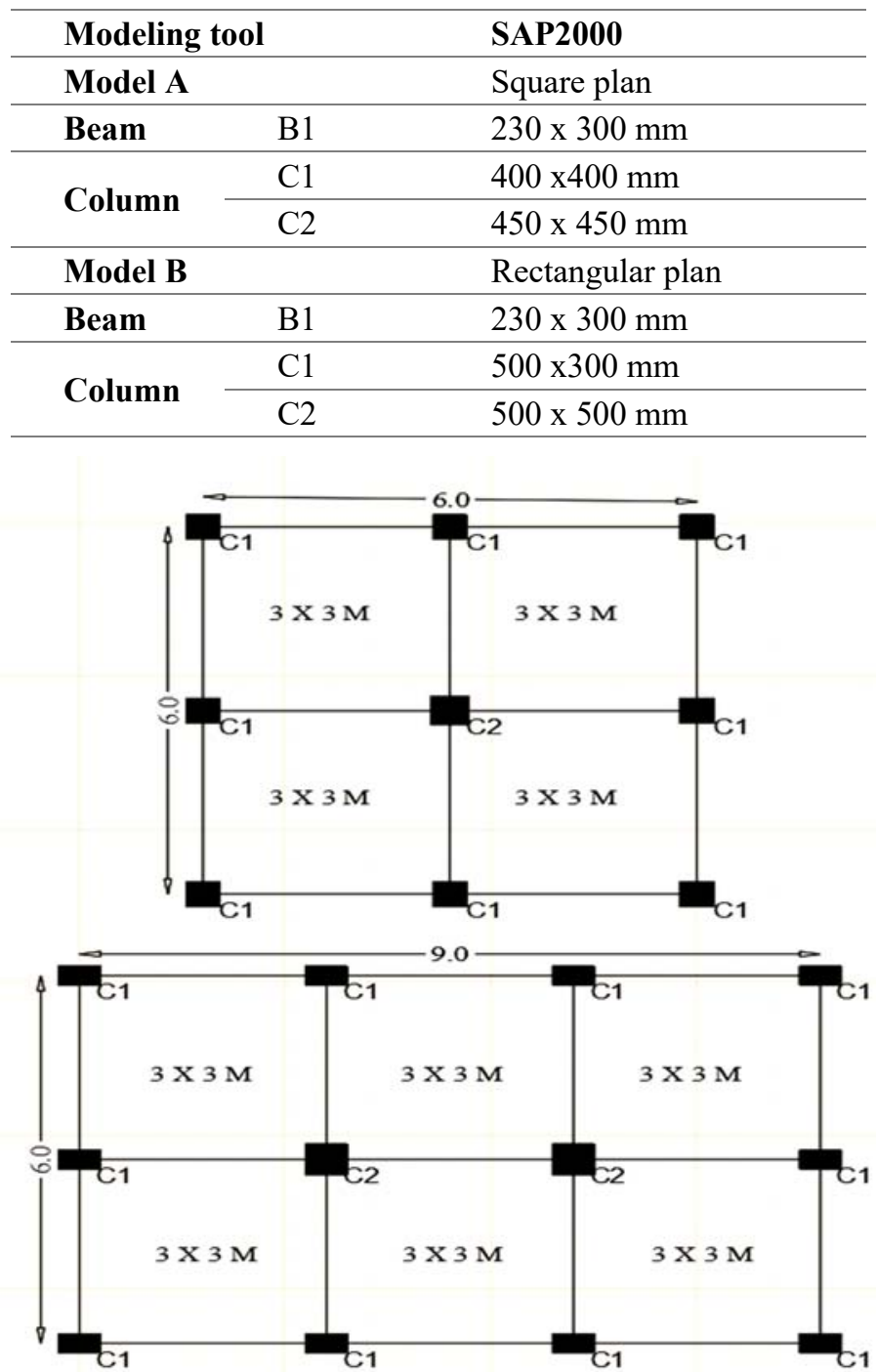

Fig 1. Modelling plans 


\section{Step1-}

Analyse model for gravity loading only and design it for the 1.5(DL+LL) load combination as per IS456 2000. Friction damper is designed for axil force which is developed due to seismic lateral loading. Thus friction dampers will not take part to carry gravity load, therefore models are previously designed for gravity loads.

\section{Step 2-}

To select of structural performance objectives- Fema-356 and ASCE 41 provided guidelines suggested that, structure should remain under immediate occupancy (IO) level for MCE earthquake.

\section{Step 3-}

To perform pushover analysis on models for determination of capacity of structure and ultimately to decide that structure needs retrofitting or not. Present study follows ATC 40 procedure for pushover analysis results interpretation. Software generated pushover curve is base shear vs roof displacement, this curve needs to be converted into capacity spectrum i.e. Acceleration-Displacement Response Spectra (ADRS) using equations 1 \& 2 given in ATC-40.

$$
\begin{aligned}
S_{a} & =\frac{V_{b}}{W / \alpha_{1}} \\
S_{a} & =\frac{\Delta_{\text {roof }}}{P F_{1} \emptyset_{1 \text { roof }}}
\end{aligned}
$$

Latter, demand curve i.e. response spectra of IS1893 (2016) is converted into ADRS format with the help of equation 3. Both capacity spectra and demand spectra are overlapped on each other as shown in figure- 2 . Reinforced concrete structure has 5\% inherent damping. If IO level is below 5\% damped demand spectra then capacity of structure is inadequate under the seismic loading. That defines structure needs to be retrofitted for seismic action. In our case both the models demand seismic retrofitting.

$$
\mathrm{S}_{\mathrm{d}}=\frac{\mathrm{T}^{2}}{4 \pi^{2}} \mathrm{~S}_{\mathrm{a}}(\mathrm{g})
$$

\section{Step 4-}

To identify required damping factor- Demand spectra for various damping ratio is plotted and overlapped with capacity spectra Fig 2. The curve for which IO level is above the damped demand spectra, is the required damping for design of friction damper. Effective required damping is found out for both models are given in TABLE .

TABLE II: Required Damping Percentage

\begin{tabular}{llll}
\hline & Model A & Model B & \\
\hline & $\mathrm{X} / \mathrm{Y}$ & $\mathrm{X}$ & $\mathrm{Y}$ \\
\hline Required damping & $30 \%$ & $20 \%$ & $30 \%$ \\
\hline
\end{tabular}

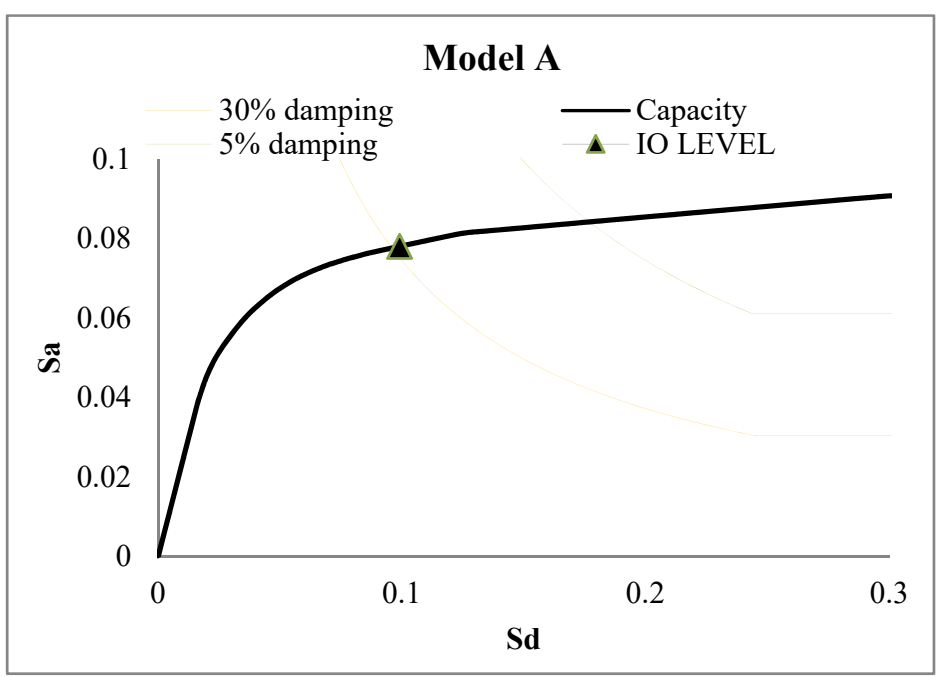




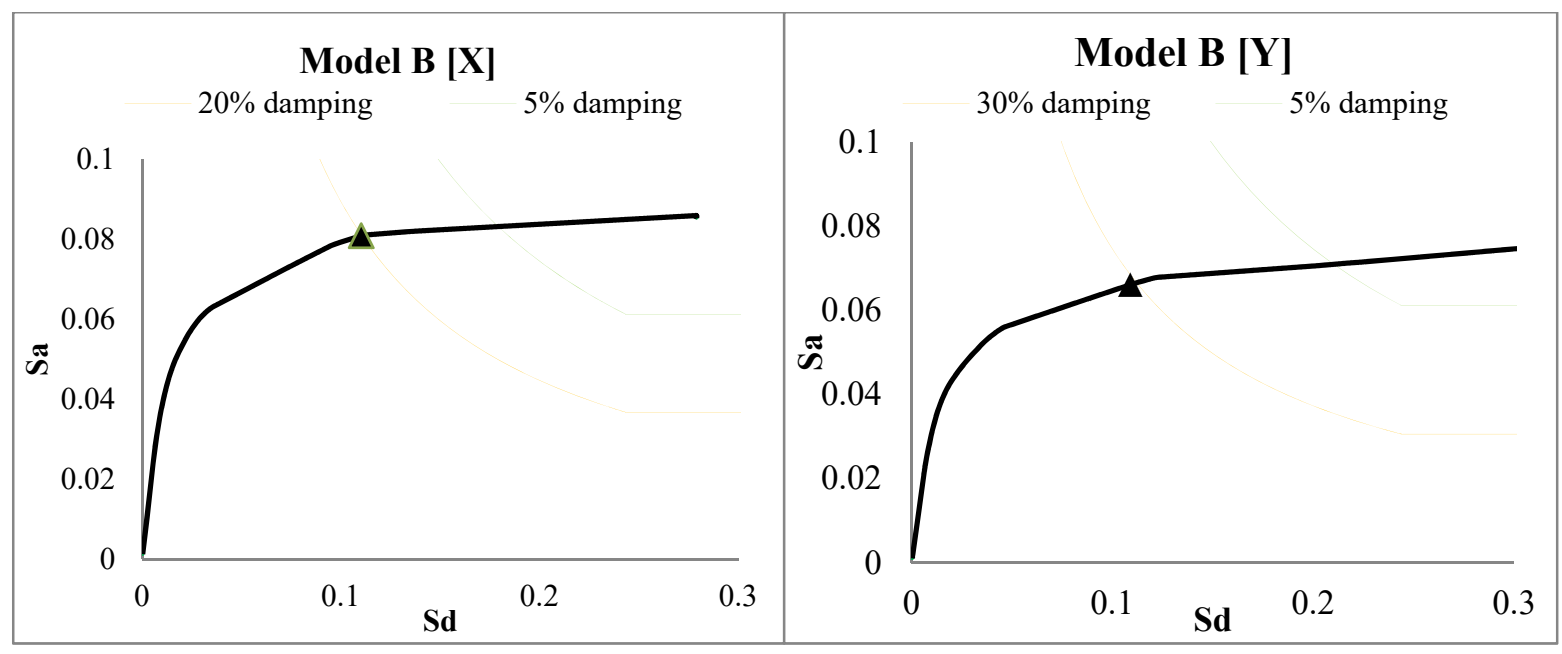

Fig 2. ADRS Plot for Structural Inherent Damping \& required damping

\section{Step 5-}

Chaudhari and singh [11] gave the design procedure for the friction damper. Bottom storey slip load is given by equation given bellow,

$$
\begin{aligned}
& F_{y d}=F_{r} * P \\
& F_{r}=\frac{\xi\left[\frac{1}{\mu}+r\left(1-\frac{1}{\mu}\right)\right]}{\left(\frac{2}{\pi}-\xi\right)}
\end{aligned}
$$

Bottom storey slip load is distributed over the entire storeys as per the storey shear, using following formula,

\section{Step 6-}

$$
F_{y d i}=\frac{F_{y d}}{\cos \theta} \frac{\sum_{i=j}^{n} \Psi_{i}}{\sum_{i=1}^{n} \varphi_{i} \Psi_{i}}
$$

Verification of retrofitting strategy- Non-linear time history analysis is performed on the retrofitted models. In present study 7 time history records were downloads from PEER data website. These records were match with response spectra of IS1893:2016 by using software Seismomatch. Matched records characteristic are shown in Table III

Table III: Time History Records Characteristic

\begin{tabular}{llll}
\hline Records & PGA $(\mathbf{g})$ & PGV $(\mathbf{c m} / \mathbf{s e c})$ & PGD $(\mathbf{c m})$ \\
\hline El-Centro & 0.23 & 25.89 & 10.24 \\
\hline Kobe & 0.23 & 24.69 & 10.78 \\
\hline Loma Prieta & 0.26 & 32.57 & 13.88 \\
\hline Kocieli & 0.37 & 55.06 & 53.26 \\
\hline Parkfield & 0.23 & 21.12 & 5.32 \\
\hline Hollister & 0.32 & 21.37 & 10.10 \\
\hline Northridge & 0.24 & 27.35 & 5.15 \\
\hline
\end{tabular}

\section{B. Design of friction dampers}

Friction dampers dissipate energy through friction between two surfaces. Governing characteristic of it is slip load/force and slip displacement. Thus investigation carried out to find out slip force required for each damper at each storey.

Table shows the damper characteristics.

Table IV: Friction Damper Parameters

\begin{tabular}{cccc}
\hline & Model A & \multicolumn{2}{c}{ Model B } \\
\hline & $\mathrm{X} / \mathrm{Y} \mathrm{kN}$ & $\mathrm{X} \mathrm{kN}$ & $\mathrm{Y} \mathrm{kN}$ \\
\hline Elastic force & 2683.6 & 7222 & 5833.2 \\
\hline Force factor & 0.196 & 0.0735 & 0.107 \\
\hline Total yield force & 528.5 & 530.9 & 625.8 \\
\hline
\end{tabular}


The yield force obtained in above step is use to find out the slip load. Yield force is distributed storey wise in accordance of inverted triangle of lateral load pattern and Normalize displacement vector at target performance level (IO). Four dampers are provided on each storey as per the guidelines of FEMA356. Connecting brace element of the damper has designed for tension and compression member as per IS800:2007 code. ISJC 100 has been used as bracing element for each damper. Table $\mathrm{V}$ gives the slip load at each damper on each storey.

Table V: Slip Load for Dampers

\begin{tabular}{cccc}
\hline \multirow{2}{*}{$\begin{array}{c}\text { Storey } \\
\text { number }\end{array}$} & Model A & \multicolumn{2}{c}{ Model B } \\
\cline { 2 - 4 } & X/Y KN & X KN & Y KN \\
\hline $\mathbf{1}$ & 106 & 122 & 138 \\
\hline $\mathbf{2}$ & 103 & 121 & 138 \\
\hline $\mathbf{3}$ & 97 & 119 & 135 \\
\hline $\mathbf{4}$ & 83 & 111 & 126 \\
\hline $\mathbf{5}$ & 61 & 95 & 108 \\
\hline $\mathbf{6}$ & 27 & 70 & 79 \\
\hline
\end{tabular}

\section{RESULTS AND DISCUSSION}

The nonlinear time history analysis for seven records has been performed on model A and Model B, before and after retrofitting. Detailed evaluation of structural response studied by comparing the various parameters such as storey displacement, storey drift, maximum axial force, shear force, moment, variation of base shear, floor acceleration and displacement with respect to time and etc. Fig 3 shows the damper assigned models.
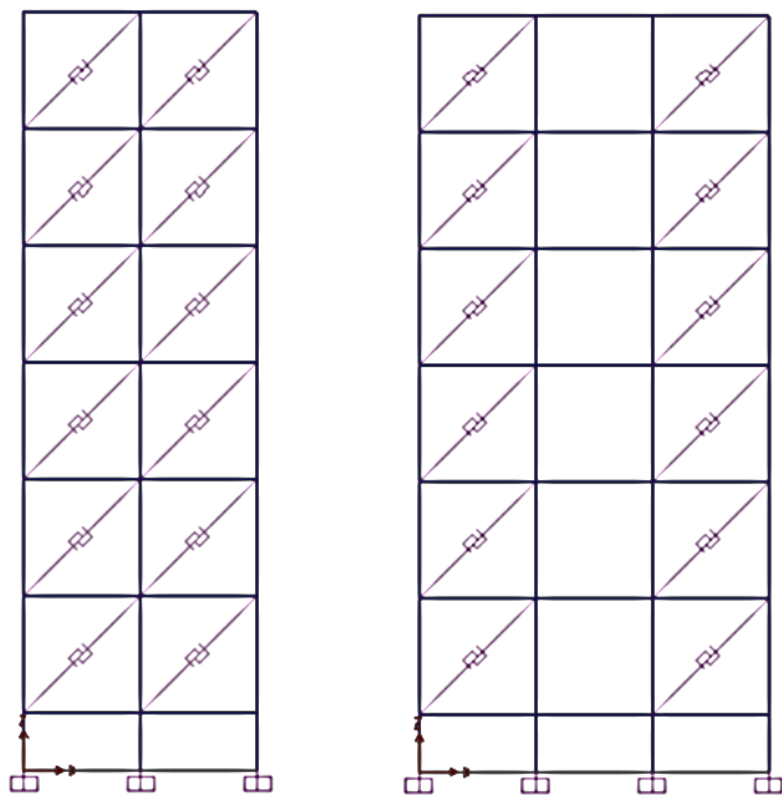

Fig 3. Distribution of dampers along height of structure

\section{A. Model A}

1. Storey displacement: Storey displacement plot is the important characteristic of seismic behaviour of structure. Fig 4 presents the plot Storey displacement as a function of storey number, for each time history record. Storey displacement for retrofitted model was reduced by $67 \%$ over the un-retrofitted model. Maximum storey displacement of $0.211 \mathrm{~m}$ found for El-Cenrto record. 


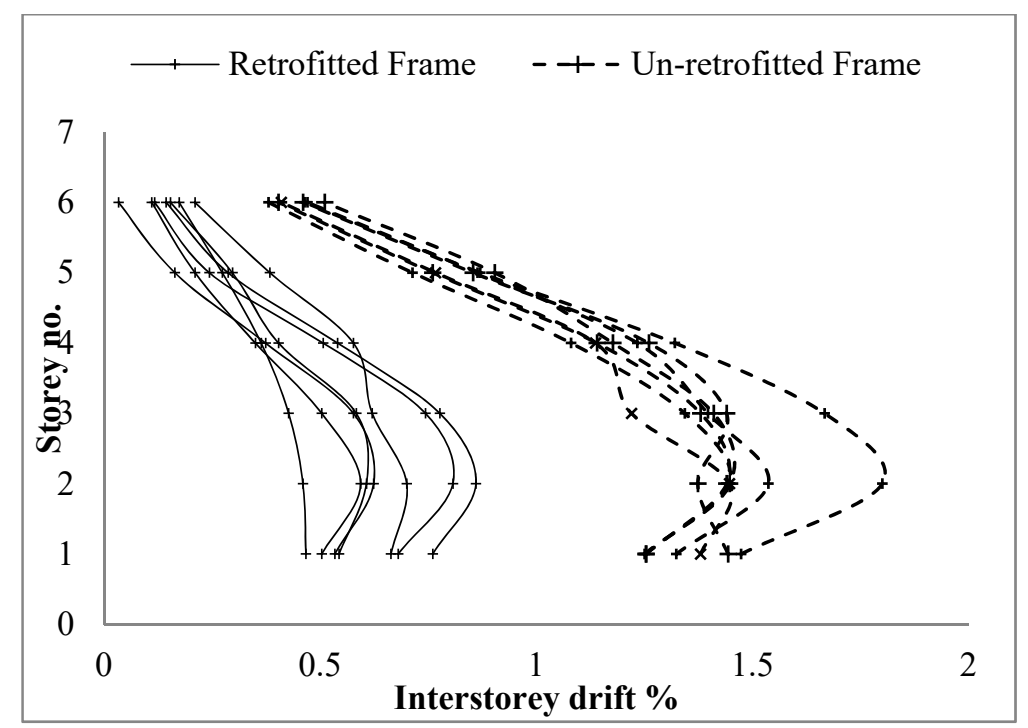

Fig 4. Storey displacement plot

2. Frame forces: Frame element are the basic and load carrying structural members, thus any variation in the forces acting on structural elements of building is worth noting. Variation of maximum frame forces for different time history records given in table VI. Axial force increase after application of friction damper and at a same time Bending moment reduced, combine effect of both shows friction damper improves the structural stability. Addition of friction dampers along with the bracing elements increases the dead load of total structure. Base shear is the function of seismic weight thus increase in base shear is recorded. Variation of shear force is quite fluctuating nature, in some records shear force before application of friction damper found maximum while in some cases shear force for without damper application found maximum.

TABLE VI: Frame Forces

\begin{tabular}{clcccc}
\hline \multicolumn{2}{c}{ Earthquake record } & $\begin{array}{c}\text { Axial force } \\
\text { KN }\end{array}$ & $\begin{array}{c}\text { Bending moment } \\
\text { KN.M }\end{array}$ & $\begin{array}{c}\text { Shear force } \\
\text { KN }\end{array}$ & $\begin{array}{c}\text { Base shear } \\
\text { KN }\end{array}$ \\
\hline \multirow{2}{*}{ El-centro } & Without damper & 909 & 252 & 561.93 & 1627 \\
\cline { 2 - 6 } & With damper & 2580 & 340.198 & 390.32 & 2488 \\
\hline \multirow{2}{*}{ Kobe } & Without damper & 892.7 & 266.094 & 576.45 & 576.4 \\
\cline { 2 - 6 } Loma & With damper & 1192 & 224.88 & 281.82 & 1473 \\
\cline { 2 - 6 } & Without damper & 827 & 250.98 & 555.8 & 1552 \\
\hline \multirow{2}{*}{ Kocieli } & With damper & 2198 & 400.73 & 452.14 & 1648 \\
\cline { 2 - 6 } & Without damper & 850.7 & 308.32 & 653.94 & 1840 \\
\hline \multirow{2}{*}{ Parkfield } & With damper & 442 & 120.47 & 263.99 & 914 \\
\cline { 2 - 6 } & Without damper & 1008 & 285.3 & 642.72 & 1701 \\
\hline \multirow{2}{*}{ Holister } & With damper & 1620 & 297.18 & 372.88 & 1893 \\
\cline { 2 - 6 } & Without damper & 907.1 & 257.92 & 563.47 & 1544 \\
\hline \multirow{2}{*}{ Worthridge } & Without damper & 848 & 242.70 & 304.18 & 1972 \\
\cline { 2 - 6 } & With damper & 1348 & 224.13 & 500.65 & 1553 \\
\hline
\end{tabular}

3. Lateral roof displacement, roof acceleration and base shear: Performance of building for roof displacement and roof acceleration incorporated with dampers is the important parameter for analysis. Fig 5 shows the time variation plot. Variation of acceleration with respect to time shows that, friction damper controlled acceleration over the latter part of time. Friction damper system reduces the Roof displacement approximately by $70 \%$ as shown in graph. As noticed, displacement for the model incorporated with friction damper has successfully been reduced displacement at all-time instant. This provides the smooth transition and prevents sudden reversal of displacement load. Time varying plot of base shear depicts that, friction dampers are less significant to control base shear acting on structure. 

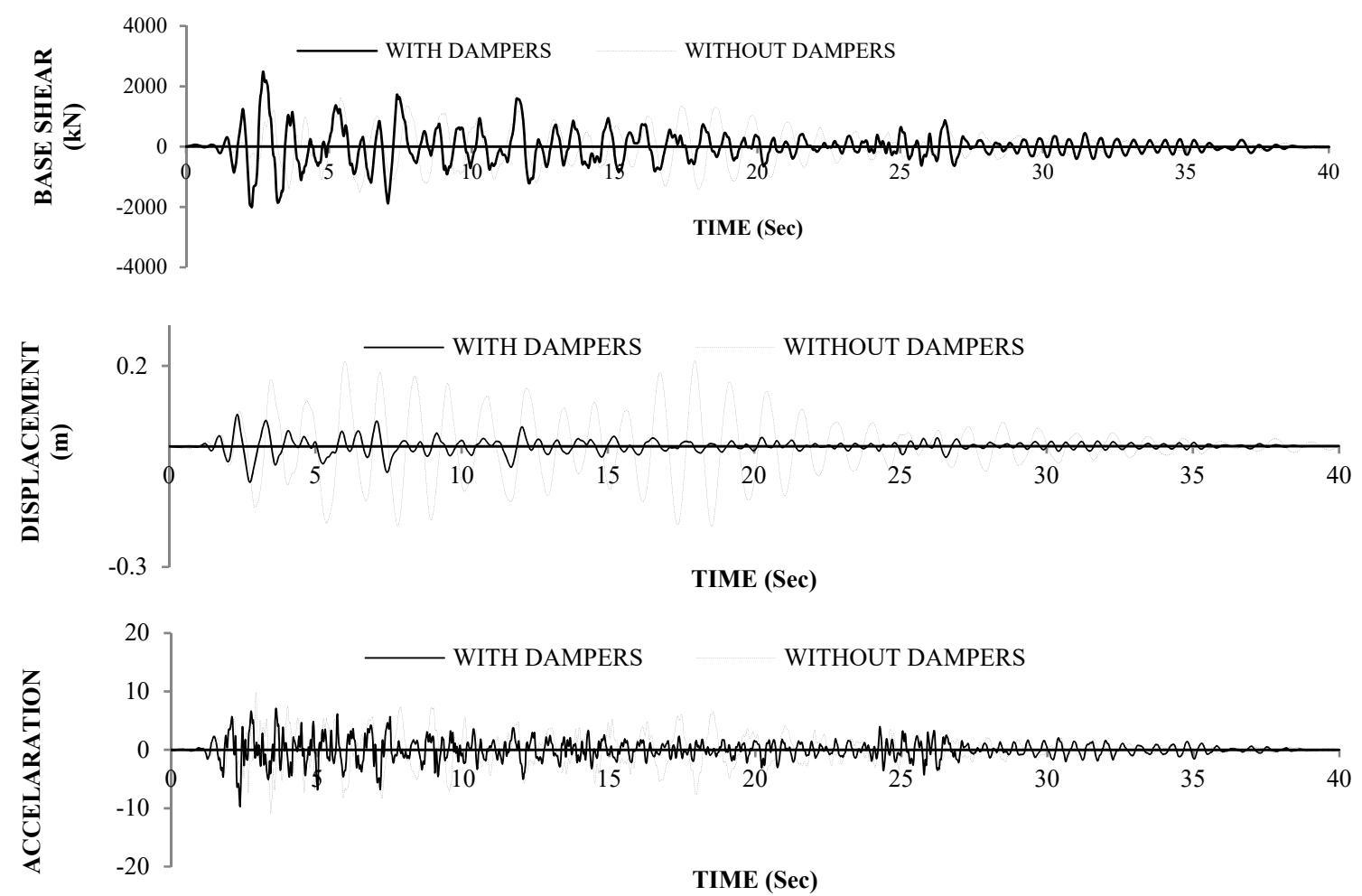

Fig 5. Timely varying plot

4. Inter-storey drift: Inter-storey drift is the controlling parameter for global retrofit of buildings. FEMA 356, ASCE 41 And ATC 40 suggested that inter-storey drift percentage should be under 1\%, and IS 1893-2016 bounded inter-storey drift to 0.004 of storey height. i.e. for our case it becomes $1.2 \%$. All the time history records found storey drift below $1 \%$ after retrofitting. Effective reduction in inter-storey drift is found approx. 50\%. Thus model A has been retrofitted successfully.

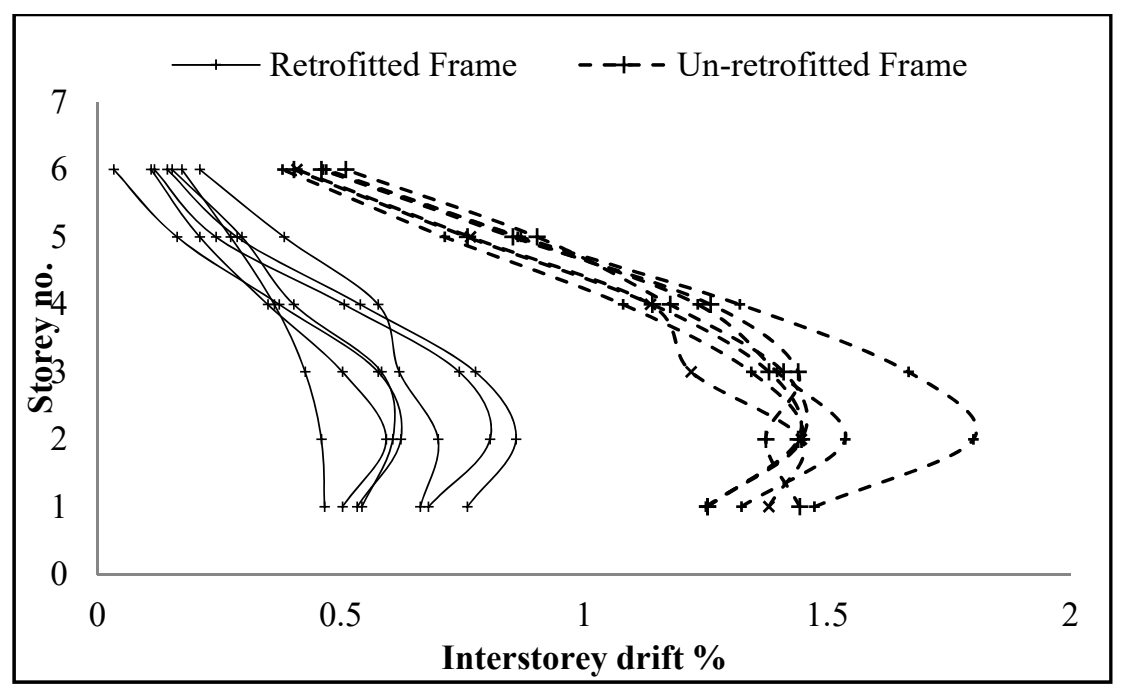

Fig 6. Inter-storey drift plot

5. Hysteretic behaviour: Tolvar studied the placement of damper and suggested that first storey damper is more effective than top storey damper. Fig shows plot for axial force as a function of displacement of friction damper. Bottom and top storey dampers yielded to their capacity and thus each storey damper is effective to control seismic action. Hysteretic loop of bottom storey is close to ideal behaviour of friction damper, as it shows the complete square shape. Top storey friction damper energy dissipation plot does not resemble to ideal shape of energy dissipation loop and stiff slip problem occurred. 


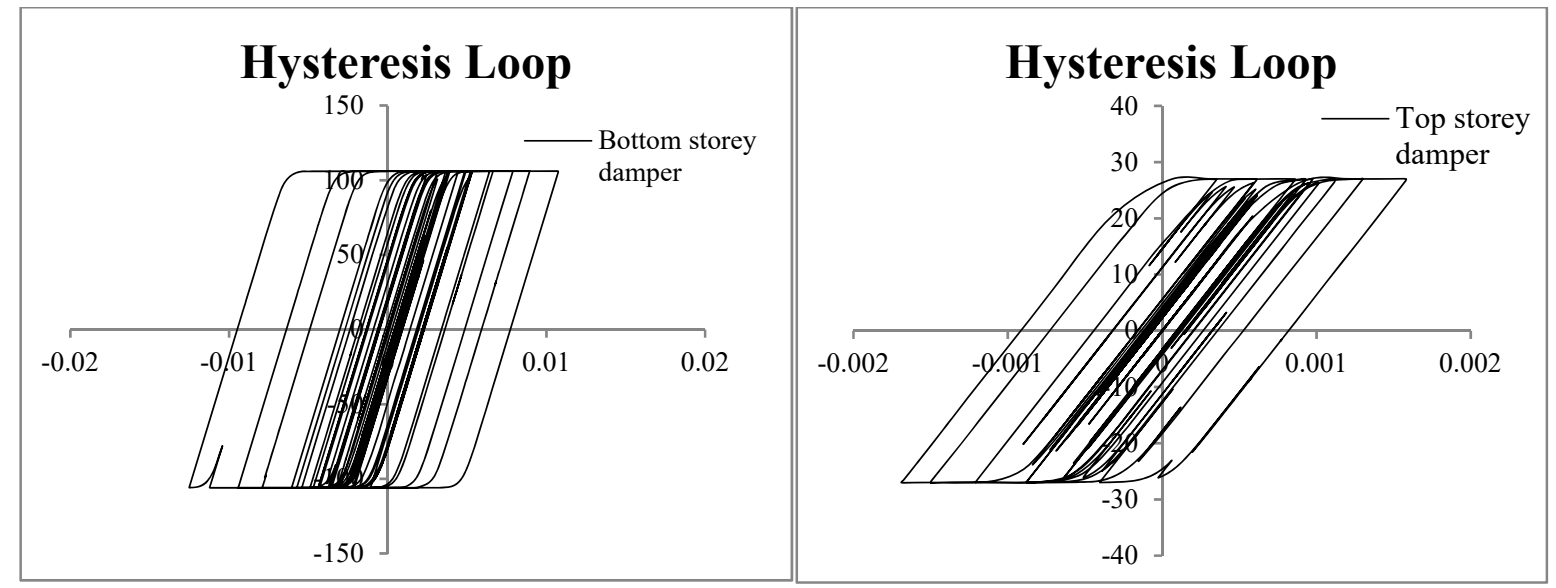

Fig 7. Hysteretic behaviour of dampers

B. Model B

1. Storey displacement: fig 8. shows storey wise displacement for each time history record. Maximum percentage reduction in storey displacement for retrofitted frame model along $\mathrm{x}$ and $\mathrm{y}$ direction is found to be $60.58 \%$ \& $63.56 \%$ respectively. Displacement controlling characteristic of friction damper can be effectively studied from this graph.

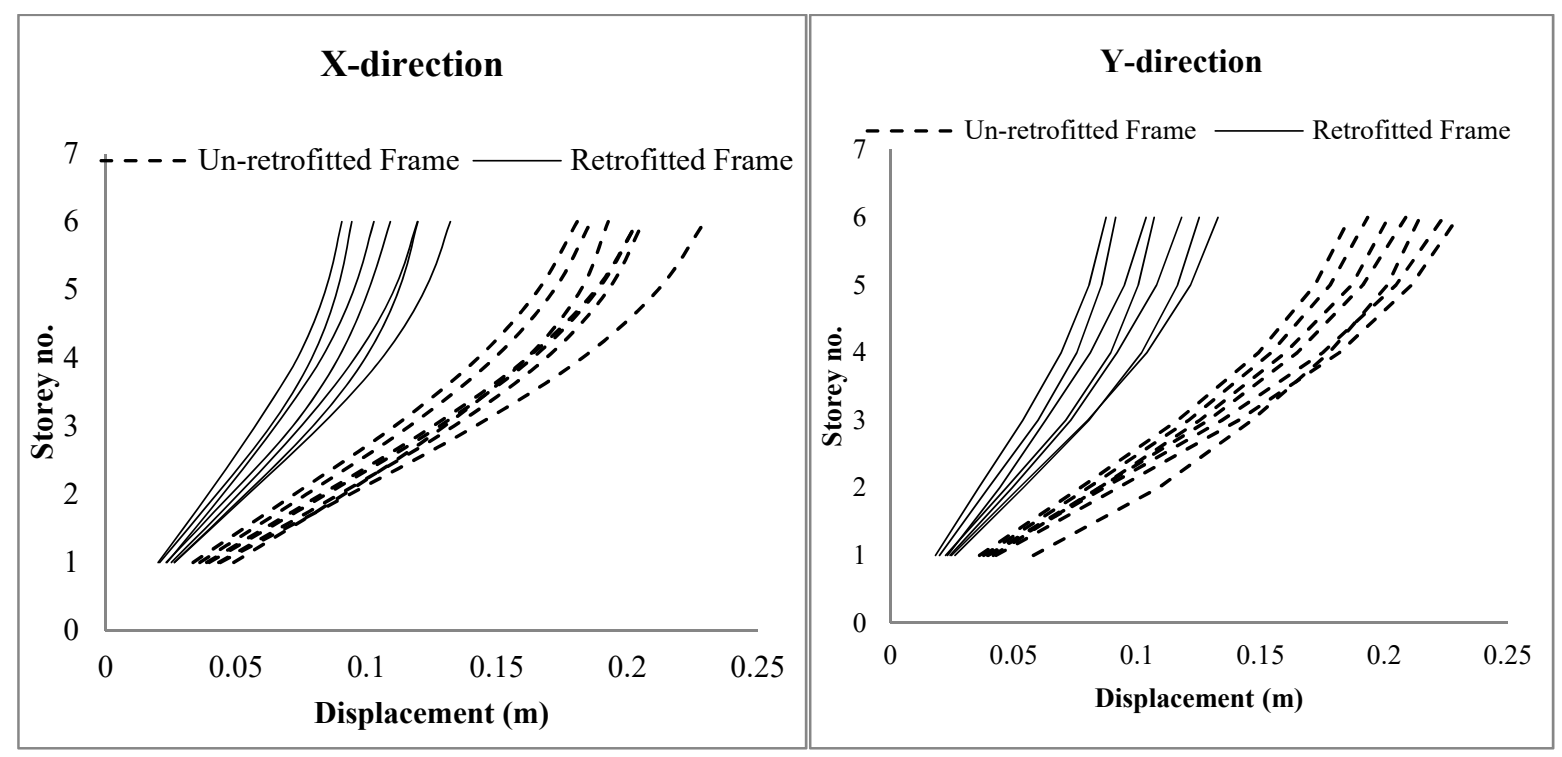

Fig 8. Storey displacement plot

2. Frame forces: Variation of maximum frame forces for different time history records given in table VII. Axial force increase after application of friction damper and at a same time bending moment reduced. Increase in base shear is recorded. Variation of shear force is quite fluctuating nature. 
Table VII: Frame Forces Variation

\begin{tabular}{cccccc}
\hline \multicolumn{2}{c}{ Earthquake record } & $\begin{array}{c}\text { Axial force } \\
\text { KN }\end{array}$ & $\begin{array}{c}\text { Bending moment } \\
\text { KN.M }\end{array}$ & $\begin{array}{c}\text { Shear force } \\
\text { KN }\end{array}$ & $\begin{array}{c}\text { Base shear } \\
\text { KN }\end{array}$ \\
\hline \multirow{2}{*}{ El-Centro } & Without damper & 916 & 289 & 778 & 2427 \\
\cline { 2 - 6 } & With damper & 1994 & 285 & 544 & 2638 \\
\hline \multirow{2}{*}{ Kobe } & Without damper & 444 & 238 & 736 & 2428 \\
\cline { 2 - 6 } Loma & With damper & 1528 & 229 & 483 & 2375 \\
& Without damper & 864 & 231 & 634 & 2444 \\
\cline { 2 - 6 } Kocaeli & With damper & 2233 & 320 & 617 & 2934 \\
& Without damper & 812 & 394 & 995 & 2560 \\
\cline { 2 - 6 } Parkfield & With damper & 2024 & 336 & 632 & 3145 \\
& Without damper & 946 & 255 & 694 & 2639 \\
\cline { 2 - 6 } Holister & With damper & 1819 & 280 & 540 & 2580 \\
\cline { 2 - 6 } & Without damper & 948 & 250 & 676 & 2563 \\
\hline \multirow{2}{*}{ Northridge } & With damper & 1714 & 232 & 450 & 2953 \\
& Without damper & 1067 & 285 & 765 & 2829 \\
\cline { 2 - 6 } & With damper & 1598 & 257 & 282 & 2407 \\
\hline
\end{tabular}

3. Lateral roof displacement, roof acceleration and base shear: Variation of base shear with respect to time shows the no significant characteristic for model B also. And variation of floor displacement with respect to time shows the considerable reduction in floor acceleration. From fig 9 it can be clearly seen roof displacement is reduced by approximately $60 \%$.
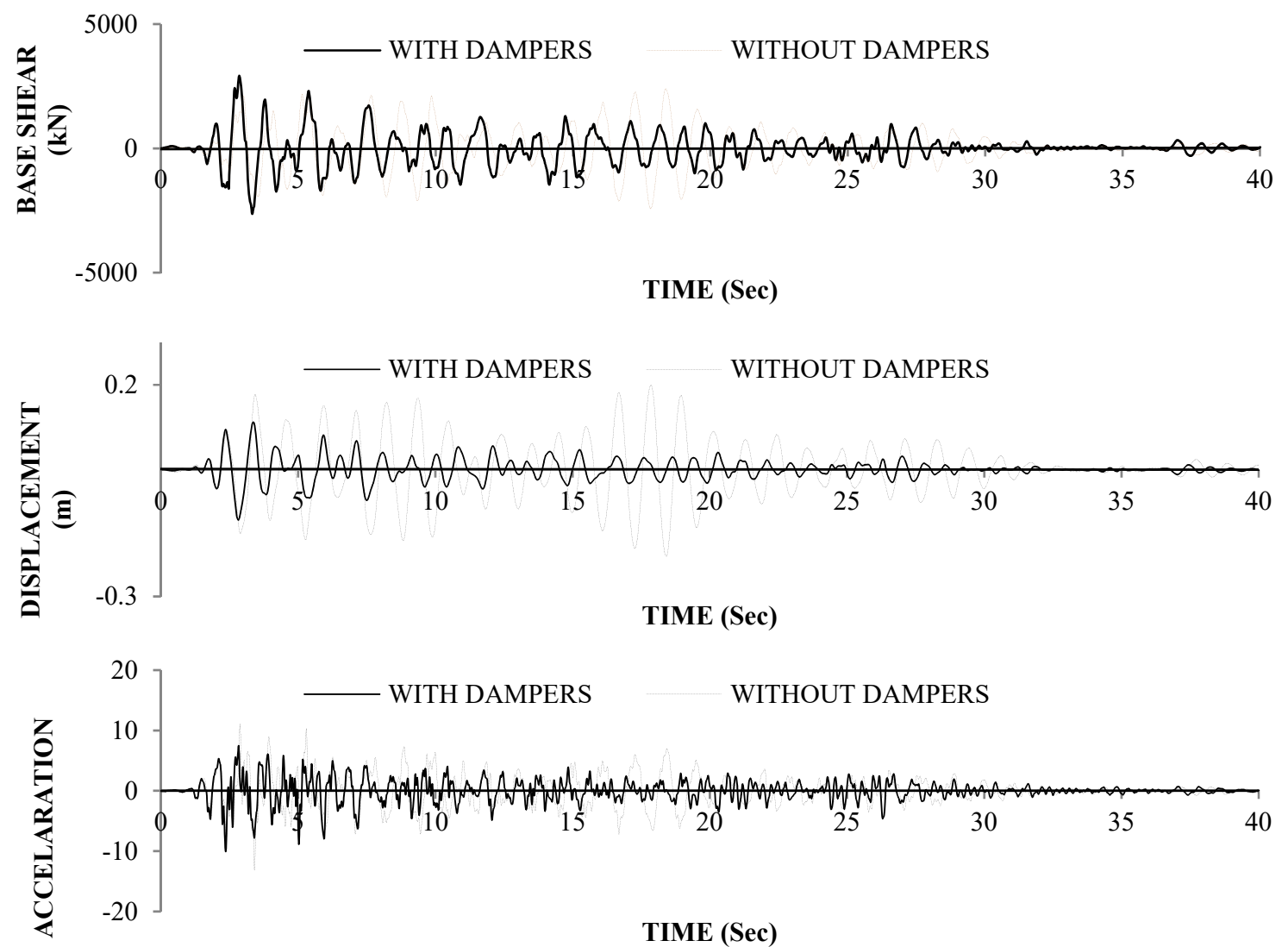

Fig 9. Timely varying plot

4. Inter-storey drift: Maximum inter-storey drift without retrofitting found $1.65 \%$ and $1.7 \%$ in $\mathrm{X} \& \mathrm{Y}$ direction respectively. Retrofitted model found $0.72 \% \& 0.83 \%$ maximum inter-storey drift. Thus reduction in drift is observed as $56 \%$. Figure shows the drift response for all records. Response is well below the $1 \%$ thus Model B is also retrofitted effectively. 

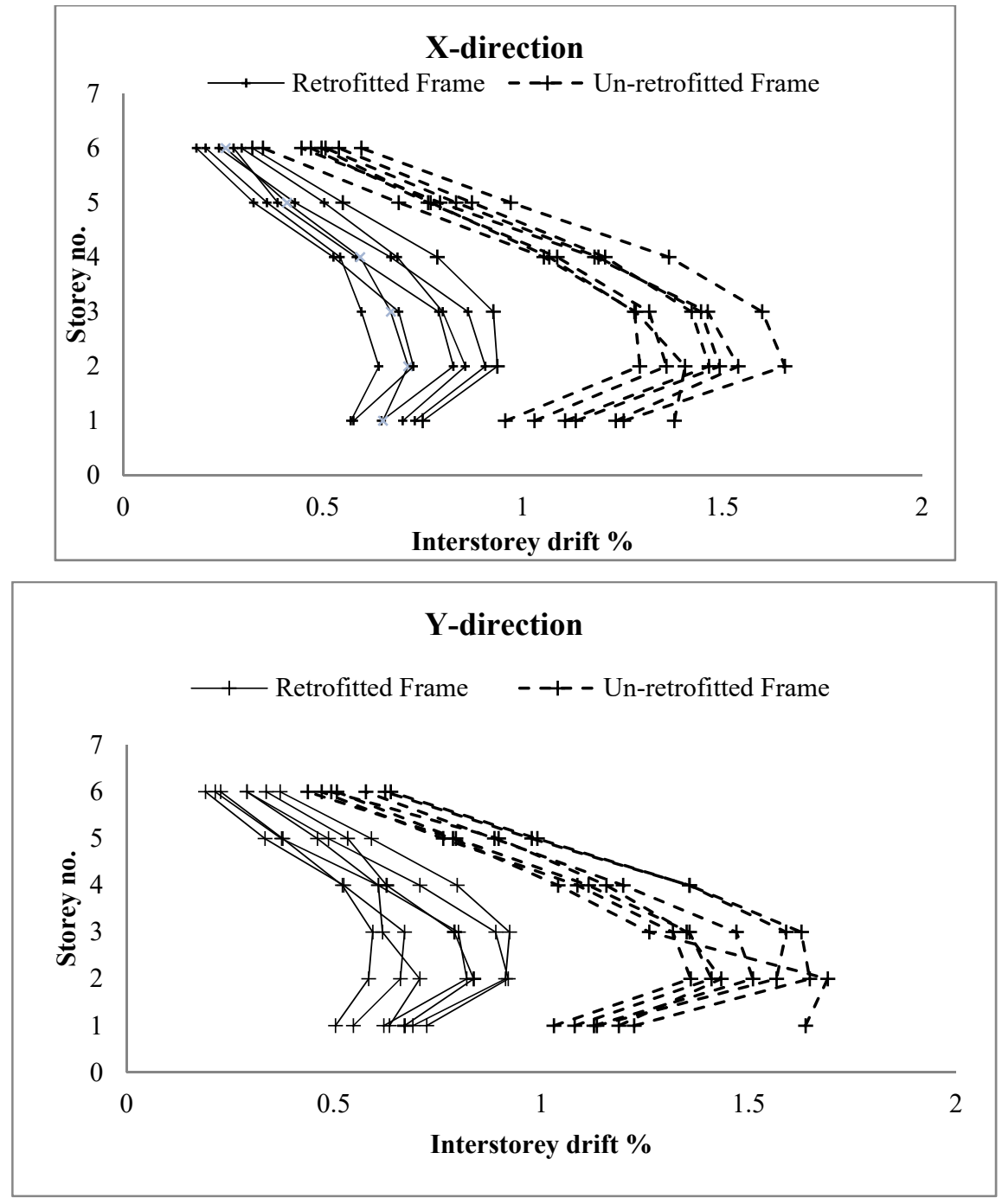

Fig 7. Inter storey drift

5. Hysteretic behaviour: All the dampers are observed to be yielded to their full capacity thus all storey dampers are effective to control response of structure. But plot of storey damper shows the stiff slip effect.

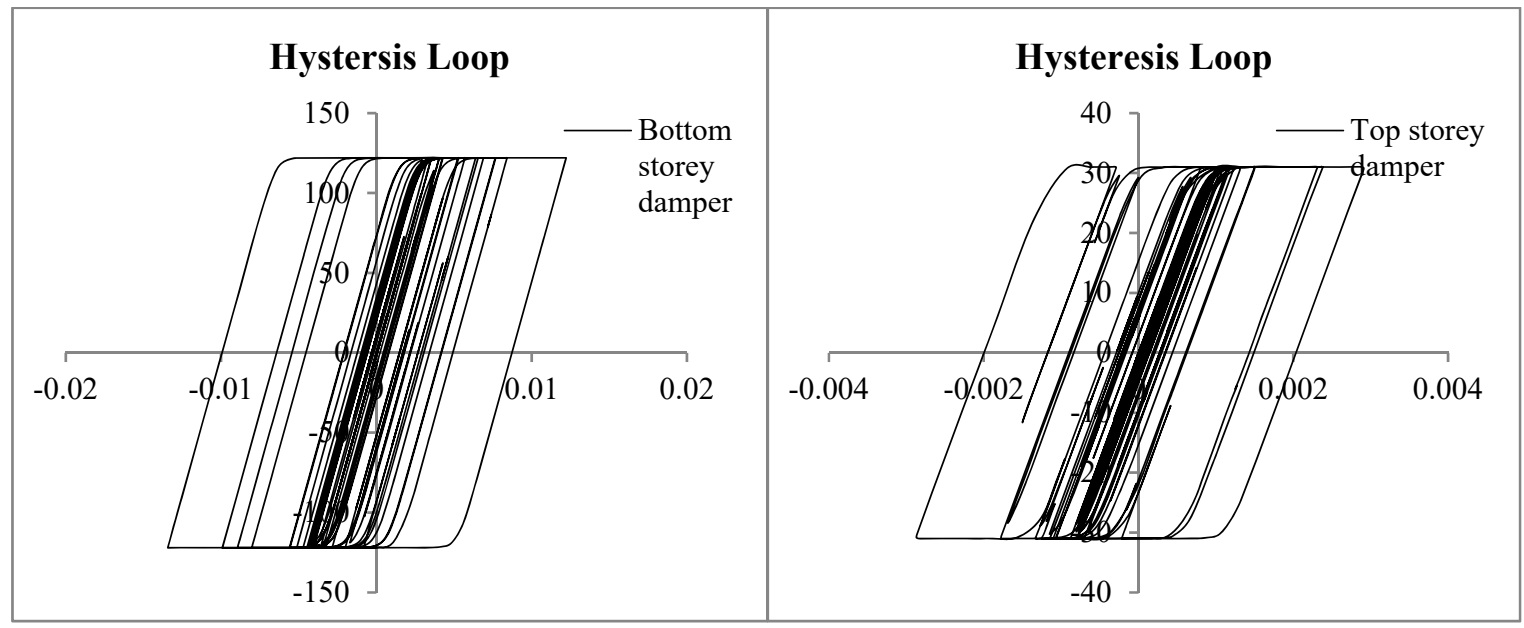

Fig 11. Hysteretic behaviour of damper 


\section{CONCLuSION}

Friction dampers are the familiar and effective damping device for seismic retrofitting of structures. In this study proper and systematic step by step procedure is demonstrated for retrofitting of mid-rise building such that target performance objectives fulfil the codal provisions. It was observed that, after seismic retrofit inter-storey drift were reduced bellow the desired limit, axial force on column increased while maximum moment on flexural member decreased. Results found effective in controlling floor displacement. Based on the result obtained, it is concluded that models considered for study were retrofitted effectively by using friction dampers.

\section{REFERENCES}

[1] FEMA-356, "Prestandard And Commentary For Seismic Rehabilitation Of Building", Federal Emergency Management Agency, Washington,DC

[2] Pekelnicky, Robert, et al. "ASCE 41-13: Seismic evaluation and retrofit rehabilitation of existing buildings." Proceedings of the SEAOC (2012).

[3] Applied Technology Council. (1996). "Seismic evaluation and retrofit of concrete buildings, Volume 1.” ATC-40, Rep. No. SSC Redwood SSC 96-01, City, CA.

[4] Standard, Indian. "Earthquake Resistant Design and Construction of Buildings Code of Practice: 1893-2016." Indian code.

[5] BIS, IS. "456 (2000) Plain and reinforced concrete-Code of Practice." Bureau of Indian Standards, New Delhi, India (2000).

[6] Standard, Indian. "General Construction in steel-Code of Practice: 2007. " Indian code.

[7] Standard, Indian. "Code of Practice for Design loads (other than earthquake for building and structure) Part1: 1987. " Indian code.

[8] Standard, Indian. "Code of Practice for Design loads (other than earthquake for building and structure) Part2: 1987. " Indian code.

[9] Ioan Olariu, Felicia Olariu And Dragos Sarbu, "Base Isolation Versus Energy Dissipation For Seismic Retrofitting Of Existing Structures", 12WCEE, 2000.

[10] Emanuele Gandelli, Andreas Taras, Johann Distl and Virginio Quaglini, "Seismic Retrofit Of Hospitals By Means Of Hysteretic Braces: Influence On Acceleration-Sensitive Non-Structural Components", Frontiers in Built Environment, Article 100, Volume 5, January 2019.

[11] Shanshan Wang, Stephen Mahin, "Seismic Upgrade of an Existing Tall Building by Different Energy Dissipation Devices", University of California, Berkeley, 2016.

[12] Deepshikha chaudhari, Yogendra singh, "Performance based design of RC frame building with metallic and friction damper",J. Inst. Eng. India Scr. A (October-December-2014).

[13] Sanghai, S. S., and P. Y. Pawade. "A Review on:'Performance of Friction Damper for Response Control of Buildings Considering Effect of Soil-Structure Interaction'." Smart Technologies for Energy, Environment and Sustainable Development. Springer, Singapore, 2019. 335-346. 